\title{
Decision-Making Styles as Predictors of Career Decision Difficulties in Secondary School Students with Regard to Gender
}

\author{
Sonja Pečjak, Anja Podlesek, and Tina Pirc \\ University of Ljubljana, Faculty of Arts, Department of Psychology, Ljubljana, Slovenia
}

\begin{abstract}
The study aimed to examine whether students' different career decision styles predict their difficulties in deciding about their future education. We measured students' adaptive self-confident and three maladaptive decision-making styles: avoidant, panic, and impulsive, and examined how these styles are related to students' difficulties in career decision-making: internal and external conflicts, lack of information, and dysfunctional beliefs. Our sample comprised 792 final-year students from 26 Slovenian secondary schools. We used the Career Decision Difficulties Questionnaire (CDDQ) and Adolescent Decision Making Questionnaire (ADMQ), which we adapted to the Slovenian language. The results showed that boys use self-confident and impulsive decision-making styles more often and panic decision-making style less often than girls do. Boys reported less internal conflicts, lack of information and dysfunctional beliefs. Among CDDQ scales, we found a strong correlation between Internal Conflicts and Lack of Information scale scores and moderate correlations of these two scales with External Conflicts. Correlations between ADMQ scales were low to moderate: Self-Confident Style scale score correlated negatively with scores on scales of all three maladaptive styles. The Lack of Information score was best predicted by the Panic Decision-Making Style score, the External Conflicts score by the Panic and Impulsive DecisionMaking Style scores, and the strongest predictors of Dysfunctional Beliefs score was the Panic Decision-Making Style score. Having more pronounced panic style and being a girl turned out to be related to more difficulties in all domains of career decision-making. Some practical career counselling implications of these findings are discussed.
\end{abstract}

Keywords: career decision-making difficulties, decision-making styles, students, gender

Tina Pirc, University of Ljubljana, Faculty of Arts, Department of Psychology, Aškerčeva 2, 1000 Ljubljana, Slovenia. E-mail: tina.pirc@ff.uni-lj.si

This paper was created within the framework of a project "Development of lifelong career guidance services and further strengthening of the National Coordination Point for lifelong career guidance", which is funded by the Republic of Slovenia and the European Union from the European Union Social Fund under the Operational Program for the Implementation of the European Cohesion Policy in the period 2014-2020. 


\section{Introduction}

\section{Career Decision-Making}

During secondary education, students are faced with numerous challenges of making various decisions - one of them being their decision about future education/studying (post-secondary or tertiary). The path to the final decision is a process which develops through several developmental stages. Super (1990) refers to five career developmental periods: growth period (0-14 years), exploration (14-25 years), establishment (25-45 years), maintenance (45-65 years), and decline (from 65 years on).

The exploration phase (14-24 years) coincides with secondary and tertiary education. For effective career development, students in this period have to carry out the developmental tasks of: (i) crystallization, in which they connect their working habits, achievement aspirations and dreams about the possibilities of what they can become into a clear vocational identity with their preferences for certain occupations, (ii) specification of career preferences, in which they explore the preferred occupations, collect information and decide for future studying, and (iii) implementation, in which they implement the occupational choice with completion of education and employment (Super, Savickas, \& Super, 1996). During the time of secondary education, students enter the stages of crystallization and specification.

The process of maturation increases students' readiness for career decisions and thus contributes to adolescents' career development. However, this process does not depend only on adolescents' characteristics, but also on psychosocial encouragement from the environment - family, wider society, and especially school environment.

In secondary school, an important part of educational work is career guidance in which school counsellors and teachers participate with different assignments: (i) career education, i.e., planned activities which enable students to develop ideas, knowledge and skills on different occupations and work fields in all subjects, (ii) information, i.e., acquiring and disseminating information about occupations and educational possibilities in labour market, (iii) assessment of adolescents' abilities and knowledge for further education/occupation, and (iv) counselling, i.e., offering help to adolescents in their career path (Watts, 1993).

Deciding what to study is a complex process, which requires substantial career maturity and adaptability of adolescents (Crites \& Savickas, 2011; as cited in Savickas \& Portfeli, 2011). Although some students make their choices without any problems, many of them face smaller or larger difficulties when they have to make a decision. 


\section{Career Indecisiveness and Career Decision-Making Difficulties}

The process of making a career decision in adolescents is often hindered or even stopped because they come across various difficulties. In order to help them, the source(s) of their difficulties have to be detected. In doing that, the decision theory by Gati, Krausz, and Osipow (1996) might be helpful. This theory assumes that when deciding about a career, an individual has to: (i) choose between numerous alternatives - fields of study or occupations; (ii) consider numerous characteristics and aspects of each study/occupation, and (iii) combine all these aspects with his/her personality characteristics. The authors of the theory designed a taxonomy of career decision-making difficulties. They defined an individual's difficulties as a deviation from an ideal process of career decision-making (i.e., the process, which leads to an ideal career decision) that results in indecisiveness or less optimal decision. They organized career decision-making difficulties into three clusters with 10 specific categories.

The first cluster - Lack of readiness - contains difficulties, which appear before the process of career decision-making even starts. This cluster comprises a lack of motivation for beginning the process of career decision-making, general indecisiveness, and dysfunctional beliefs with irrational expectations and reflections. The second cluster - Lack of information - includes four categories of difficulties, i.e. difficulties related to lack of information about the process of career decisionmaking, about self, about occupations/study fields, and about ways of obtaining (additional) information. The third cluster-Inconsistent information - includes three specific categories: unreliable information, internal conflicts, and external conflicts. Based on this taxonomy of difficulties, Gati et al. (1996; Gati, Krausz, \& Osipow, 2011) developed the Career Decision Difficulties Questionnaire - CDDQ. They emphasized that career indecision could be the consequence of a single difficulty or of a combination of more problems.

The research results about career decision-making difficulties regarding gender are not consistent. In some studies, the differences between genders in general were not significant (e.g. Albion, 2000; Babarović \& Šverko, 2011). In other studies, the results showed significant differences in specific categories of difficulties. Albion (2000) and Zagoričnik and Pečjak (2007) found that boys had more difficulties with lack of motivation than girls did. On the other hand, Zhou and Santos (2007) found that male participants generally experienced fewer difficulties than female participants in career decision-making.

\section{Decision-Making Styles}

Decision-making style is one of the key intrapersonal factors that define an individual's success in the process of career decision-making. It refers to a learned, usual, prevailing pattern of an individual's response when he or she has to cope with 
a situation prompting a decision (Galotti et al., 2006; Sager \& Gastil, 1999). Career decision-making style describes the way individuals collect, perceive and process information through their career decision-making process (Gati, Landman, Davidovitch, Asulin-Peretz, \& Gadassi, 2010).

An individual's success in the process of career decision-making depends on the way a career decision was made - whether it was planned, thoughtful and autonomous, or, on the contrary, it was derived without proper reflection, irresponsibly, without weighing different occupational alternatives, or was even based on other people's decisions.

Planned and thoughtful deciding in the field of career orientation means that a student: (i) is aware of the fact that by the end of secondary school, he/she will have to make an important decision about future education; (ii) is prepared to think about various study programmes; (iii) is aware of the consequences of individual alternatives; (iv) searches and collects information which enable him/her to evaluate the suitability of specific study programmes he/she considers; (v) evaluates the advantages and disadvantages of different study programmes, and (vi) chooses three most appropriate programmes for future education (Janis \& Mann, 1977).

There are different classifications of career decision-making styles. A wellknown classification by Harren (1979) suggests three styles: rational (making decisions deliberately and logically), intuitive (making decisions based on feelings and emotional satisfaction), and dependent decision style (making decisions based on the expectations and opinions of others). Scott and Bruce (1995) added two more styles to Harren's classification - avoidant (characterized by decision-making procrastination) and spontaneous style (getting through the decision-making process as quickly as possible). Tuinstra, Van Sonderen, Groothoff, Van den Heuvel, and Post (2000) speak about the following four styles: self-confident (resembles the rational style), avoidant (individual avoids decision-making and taking responsibility for deciding), impulsive (resembles the spontaneous style), and panic style. Only the self-confident style is adaptive, others are less adaptive or maladaptive.

Studies that considered differences in decision-making styles in general with regard to gender were mostly performed on adults and their results were inconsistent. Some showed that men use the self-confident style more frequently than women do, whereas women use the panic or avoidant style more often (Friedman \& Mann, 1993; Güçray, 1998, as cited in Cenkseven-Önder, 2012). Other studies showed that men are more inclined to use the avoidant style (Bacanli \& Sürücü, 2006, as cited in Cenkseven-Önder, 2012) and that women use the self-confident style more often (Brown \& Mann, 1990).

The results of studies performed on adolescents are not consistent either. According to Cenkseven-Önder (2012) and Tuinstra et al. (2000) girls used more self-confident and boys more avoidant decision-making style, however, in the same studies, authors found differences between genders in panic decision making style. Namely, Cenkseven-Önder (2012) found that panic style was more pronounced in 
girls and Tuinstra et al. (2000) reported that panic style was more frequently used by boys.

\section{Decision-Making Styles and Career Decision-Making Difficulties}

There is some evidence that an individual's decision-making style is associated with career decision-making difficulties. Maladaptive decision-making styles are usually negatively connected with progress in the process of making a career choice (Franken \& Muris, 2005; Phillips, Pazienza, \& Walsh, 1984). Farrar (2009) found that students with an extravert decision-making and affect-oriented (panic) style have more difficulties with making a career choice. He also discovered that students with introvert style and those with a prevailing reflective (confident) style of decisionmaking have fewer difficulties.

Čerče and Pečjak (2007) found that in comparison to students with less adaptive decision-making styles, students with the self-confident decision-making style had significantly fewer difficulties in career decision-making in general as well as more specifically due to lack of readiness for deciding, lack of information, and inconsistent information. In addition, Pečjak and Košir (2007) discovered that students, who were still undecided a month before making the final decision used the avoidant and panic style significantly more often and self-confident style significantly less often than their peers who already made their career choice. They also found the panic and impulsive decision-making styles to be weak, but statistically significant predictors of career decision-making difficulties.

\section{Research Goals}

In the present study, we focused on Slovenian students at the end of secondary school. The aim of the study was to explore how students' different career decision styles predict their difficulties in deciding about their future education. In Slovenia, students have to choose their study programme in their last study year until the middle of March. Therefore, school counsellors begin the most intensive work with students regarding their final decision-making usually in December (3-4 months before students fill out the study application form). From our fieldwork experiences with school counsellors, around $75 \%$ of students have not reached their decision yet in December.

We examined the use of self-confident decision-making style and three maladaptive decision-making styles: avoidant, panic, and impulsive decisionmaking in students. Their difficulties in career decision-making - internal and external conflicts, lack of information, and dysfunctional beliefs - were considered as criterion variables.

According to previous research (Čerče \& Pečjak, 2007; Gati et al., 2010; Gati, Gadassi, \& Mashiah-Cohen, 2012), we assumed that in comparison to maladaptive 
decision-making styles, the self-confident decision-making style would predict fewer difficulties in all fields of career decision-making - less internal and external conflicts, less lack of information, and less dysfunctional beliefs. Due to inconsistent findings on the predictive role of gender in previous studies, we also added student gender as one of the predictors of difficulties in deciding about future study programme.

\section{Method}

\section{Participants}

Our sample included 792 final-year students from 26 secondary schools from 12 Slovenian statistical regions. The multistage sampling method was used. One technical upper-secondary school and one general upper secondary school (gymnasium) per region were planned to be randomly sampled, except in larger regions where more schools were sampled and in small regions where different secondary education programmes are carried out within the same school centre. Students enrolled into five different upper-secondary education programmes were sampled: a 4-year general upper secondary education programme, 4-year technical upper-secondary education programme, 4-year vocational education programme, 1year Matura classes, and 1-to-2-year vocational classes (see Eurydice, n. d., for the description of the upper secondary education system in Slovenia). The planned number of sampled students was proportional to the regional size of the population of students enrolled in five types of programmes. A class of students was sampled randomly within each school and all students from the class who agreed to participate were tested. Another class was added to the sample if needed until the number of students from a certain educational programme exceeded the planned quota.

The final sample included $405(51.1 \%)$ boys and 387 (48.9\%) girls. The structure of the sample resulted in a slight over-representation of students coming from general (48.4\%) and vocational (18.5\%) programmes and under-representation of students coming from technical programmes (33.1\%). Students were between 16 and 25 years old $(M=17.59$ years, $S D=0.89$ years).

Considering the fact that in Slovenia approximately $85 \%$ of students (Taštanoska, 2014) continue with their education after secondary school, we believe that the sample was homogenous enough to conduct our analyses on all students.

\section{Procedure}

Data collection in schools took place in December 2017. After acquiring parental consents for under-aged students and consents from full aged students (18 or more) to participate in our study, school counsellors administered the Career 
Decision Difficulties Questionnaire - CDDQ and Adolescent Decision Making Questionnaire - ADMQ during regular school hours. Students needed approximately 15 minutes to fill in the questionnaires.

\section{Instruments}

We adapted the Career Decision Difficulties Questionnaire and Adolescent Decision Making Questionnaire to the Slovenian language. The questionnaires were translated into Slovene and back-translated for the authors' approval.

Career Decision Difficulties Questionnaire - CDDQ (see also Pečjak et al., 2018b) was derived from the original online CDDQ (Gati et al., 2011). However, in our sample, we were not able to confirm the original structure proposed by the authors. Confirmatory factor analysis showed a bad fit of the model to the empirical data, $\chi^{2}(515)=2382.72, p<.001$, scaled CFI $=.844$, RMSEA $=.066$. Our exploratory factor analysis yielded four scales with satisfactory reliability coefficients: (i) the Internal conflicts scale with 10 items, including unclear perceptions of one's abilities and possible occupations, discrepancy between abilities and occupational demands and general decision-making difficulties. An example of the item was: I find it difficult to make a career decision because I do not know how to obtain additional information about myself (for example, about my abilities or my personality traits). Cronbach's $\alpha$ coefficient for the scale was .89; (ii) the Lack of information scale with 7 items about students being unfamiliar with the process of career decision-making and lack of information about occupations or study programmes. An example item: I find it difficult to make a career decision because I do not have enough information about the variety of occupations or training programmes that exist. Cronbach's $\alpha$ coefficient was .91; (iii) the External conflicts scale with 3 items regarding conflict between one's own opinion and the opinions of important others/parents; I find it difficult to make a career decision because there are contradictions between the recommendations made by different people who are important to me about the career that suits me or about what career characteristics should guide my decisions. Cronbach's $\alpha$ coefficient was .81; and (iv) the Dysfunctional beliefs scale with 3 items about unreal and too high expectations considering study programme choice, e.g., I believe there is only one career that suits me. Cronbach's $\alpha$ coefficient for this scale was .62.

The tested Slovenian version of the Adolescent Decision Making Questionnaire - ADMQ (see also Pečjak et al., 2018a) had the same structure as the original version of the ADMQ (Tuinstra et al., 2000). The ADMQ measures four decision-making styles: (i) the Self-confident style scale included 6 items about a person's trust in his/her abilities to make a good decision by carefully exploring different options and weighing their advantages and disadvantages (e.g., I think that I am a good decision maker), (ii) the Avoidance style scale has 6 items about not taking responsibility for making a decision, but rather avoiding it or leaving it to someone else (I avoid making decisions.), (iii) the Panic style scale includes 5 items about feelings of agitation 
when the decision has to be made in a short period of time (e.g., I panic if I have to make decisions quickly.), and (iv) the Impulsive style scale with 5 items about making a decision quickly without carefully reflecting it or paying much attention to it (e.g., I put a little effort into making decisions.).

To examine the correspondence of the structure of the Slovenian adaptation of ADMQ with the structure of the original version of the instrument, we performed a confirmatory factor analysis for ordinal items with a low number of categories with R packages lavaan (Rosseel, 2012) and semTools (Jorgensen, Pomprasertmanit, Schoemann, \& Rosseel, 2018). The WLSMV estimator and Satorra-Bentler method of model comparison were used. The configural model did not show a satisfactory fit, $\chi^{2}(406)=1837.32, p<.001$, scaled CFI $=.893$, RMSEA $=.092$. This is why an exploratory factor analysis on polychoric correlations was used in the next step. Parallel analysis suggested a four-factor solution. Inspection of loadings indicated that the same four factors as in the original version would be obtained if 4 out of 22 items were excluded due to their high complexity (cross-loadings) - items 15, 17, 19 , and 21 - and all other items would compose the same scales as in the original version. A model with four items excluded showed a good enough fit, $\chi^{2}(258)=$ $749.64, p<.001$, scaled CFI $=.968$, RMSEA $=.059$. Cronbach's alpha coefficients showed that factors with the remaining items had satisfactory internal consistencies: $\alpha=.83$ for the Avoidance decision-making style, $\alpha=.72$ for the Self-confident style, $\alpha=.75$ for the Panic style, and $\alpha=.75$ for the Impulsive style. The averages of responses to the remaining items of each factor were used as scale scores in further analyses.

\section{Data Analysis}

Descriptive statistics were calculated separately for boys and girls. Correlations between gender and the CDDQ and ADMQ scale scores were calculated. Next, four hierarchical linear regressions with two steps were performed, one for predicting each of the ADMQ scale scores. In the first step, gender was entered as a predictor into the model. In the second step, CDDQ scale scores describing the expression of four decision-making styles were simultaneously entered in the model as additional predictors. All statistical hypotheses were tested at the 5\% alpha error rate, except if stated differently in the text.

\section{Results}

\section{Gender Differences}

As the boys and girls subsamples were large, we used Welch's $t$-test to estimate the difference between genders on different scale scores. Results are shown in Table 1. Statistically significant differences between boys and girls were found for several scale scores. Compared to girls, boys reported to use slightly more often the self- 
Pečjak, S., Podlesek, A., Pirc, T.:

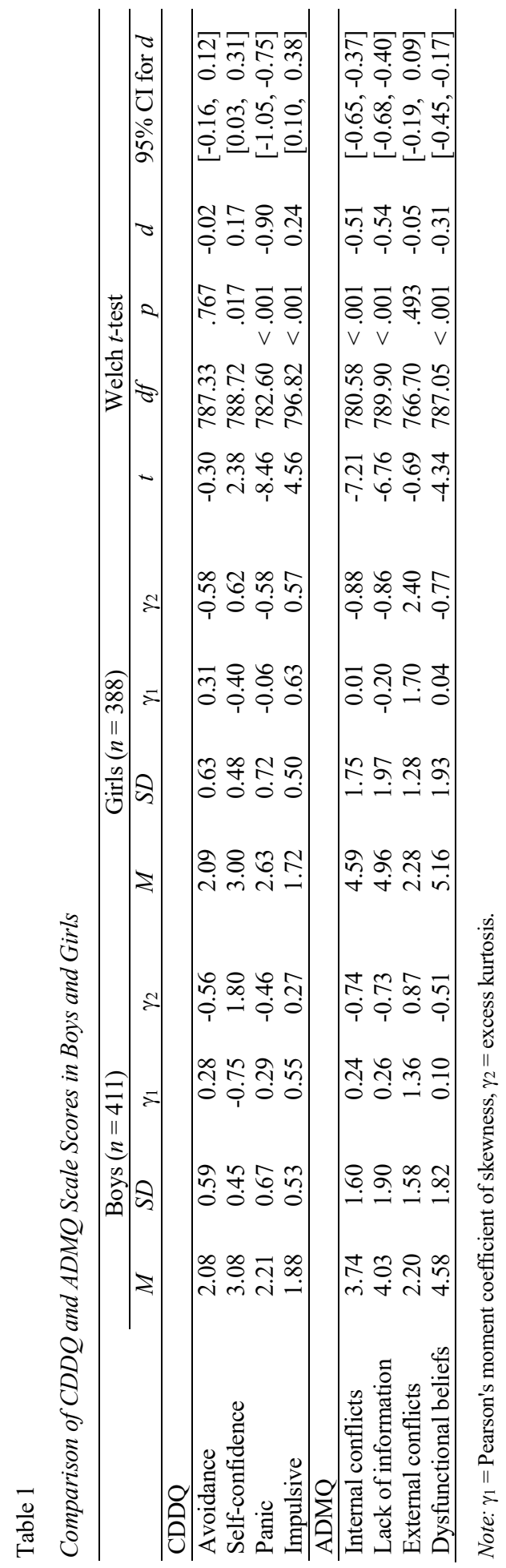


confident and impulsive decision-making styles and less often the panic decisionmaking style (for the latter difference, the effect size expressed with Cohen's $d$ was large). Boys also reported statistically significantly less internal conflicts and lack of information (gender differences were moderate) and less dysfunctional beliefs (the effect was small). There were no statistically significant differences between boys and girls regarding the External Conflicts scale score and the Avoidance DecisionMaking Style scale score.

\section{Predictors of Career Decision-Making Difficulties}

Table 2 shows correlation between different scale scores in boys and girls. The correlation between the two subsamples was comparable. Among CDDQ scales, we found a strong correlation between Internal Conflicts and Lack of Information scale scores (.76 for boys and .75 for girls) and moderate correlations of these two scales with External conflicts (between .39 and .48). Correlations between ADMQ scales were low to moderate, in line with our expectations. Adaptive, i.e. Self-confident style correlated negatively with all three maladaptive styles. Among the maladaptive styles, the strongest correlations were found between the Panic and Avoidance style scale scores (.45 for boys and .46 for girls). Point-biserial coefficients of the correlation between gender and decision-making styles were the following: .01 for the Avoidance style, -.09 for the Self-confident style, .29 for the Panic style, and -.16 for the Impulsive style. Correlations between gender and the difficulties in making career decisions were small as well: .25 for the Internal conflicts, .23 for Lack of information, .02 for External conflicts, and .15 for Dysfunctional beliefs.

Table 2

Correlations between the CDDQ and ADMQ Scale Scores in Boys ( $n=411$, Below Diagonal) and Girls ( $n=388$, Above Diagonal)

\begin{tabular}{lcccccccc}
\hline & 1 & 2 & 3 & 4 & 5 & 6 & 7 & 8 \\
\hline $\begin{array}{l}\text { 1. Internal } \\
\text { conflicts }\end{array}$ & & $.75^{* * *}$ & $.40^{* * *}$ & -.11 & $.51^{* * *}$ & $-.44^{* * *}$ & $.43^{* * *}$ & $.21^{* * *}$ \\
$\begin{array}{l}\text { 2. Lack of } \\
\text { information }\end{array}$ & $.76^{* * *}$ & & $.39^{* * *}$ & -.10 & $.29^{* * *}$ & $-.23^{* *}$ & $.29^{* * *}$ & .14 \\
$\begin{array}{l}\text { 3. External } \\
\text { conflicts }\end{array}$ & $.48^{* * *}$ & $.42^{* * *}$ & & .03 & $.22^{* *}$ & $-.19^{*}$ & $.19^{* *}$ & $.15^{*}$ \\
$\begin{array}{l}\text { 4. Dysfunctional } \\
\text { beliefs }\end{array}$ & .07 & .09 & -.01 & & -.06 & .10 & .07 & -.05 \\
$\begin{array}{l}\text { 5. Avoidance } \\
\begin{array}{l}\text { 6. Self- } \\
\text { confidence }\end{array}\end{array}$ & $.41^{* * *}$ & $.27^{* * *}$ & $.16^{*}$ & -.00 & & $-.50^{* * *}$ & $.46^{* * *}$ & $.29^{* * *}$ \\
7. Panic & $-.25^{* * *}$ & $-.20^{* * *}$ & .07 & $-.45^{* * *}$ & & $-.44^{* * *}$ & $-.23^{* *}$ \\
8. Impulsive & $.39^{* * * *}$ & $.33^{* * *}$ & $.17^{* *}$ & $.12^{*}$ & $.45^{* * *}$ & $-.38^{* * *}$ & & -.05 \\
\hline
\end{tabular}

${ }^{*} p<.05 ;{ }^{* *} p<.01 ;{ }^{* * *} p<.001$. 
Table 3 shows the results of the four linear regression analyses for predicting the career decision-making difficulties based on gender (entered in the models as the only predictor in Step 1) and decision-making styles (added as predictors in Step 2). With the variables included in the regression models, we were able to explain the largest amount of differences between individuals in the domain of Internal conflicts (36\% variance was explained overall), followed by Lack of information (17\%), External conflicts (7\%) and Dysfunctional beliefs (5\%).

Table 3

Regression Models for Predicting Career Decision Making Difficulties

\begin{tabular}{lcccc}
\hline Predictors $\beta$ & $\begin{array}{c}\text { Internal } \\
\text { conflicts }\end{array}$ & $\begin{array}{c}\text { Lack of } \\
\text { information }\end{array}$ & $\begin{array}{c}\text { External } \\
\text { conflicts }\end{array}$ & $\begin{array}{c}\text { Dysfunctional } \\
\text { beliefs }\end{array}$ \\
\hline Step 1 & & & & \\
\hline$R^{2}$ & .06 & .05 & .00 & .02 \\
$F(1,797)$ & $52.22^{* * *}$ & $45.77^{* * *}$ & .47 & $18.85^{* * *}$ \\
Gender & $.25^{* * *}$ & $.23^{* * *}$ & .02 & $.15^{* * *}$ \\
\hline Step 2 & & & & \\
\hline$\Delta R^{2}$ & .29 & .12 & .07 & .03 \\
$F(4,793)$ & $86.98^{* * *}$ & $29.01^{* * *}$ & $14.96^{* * *}$ & $5.92^{* * *}$ \\
Gender & $.18^{* * *}$ & $.17^{* * *}$ & -.00 & $.11^{* *}$ \\
Self-confidence & $-.19^{* * *}$ & -.06 & $-.08^{* *}$ & $.12^{* *}$ \\
Avoidance & $.24^{* * *}$ & $.13^{* *}$ & .06 & -.04 \\
Panic & $.23^{* * *}$ & $.23^{* * *}$ & $.13^{* *}$ & $.16^{* * *}$ \\
Impulsive & $.09^{* *}$ & .07 & $.13^{* * *}$ & -.03 \\
\hline
\end{tabular}

${ }^{*} p<.05 ;{ }^{* *} p<.01 ;{ }^{* * *} p<.001$.

Table 3 shows that the strongest predictors of the Internal Conflicts scale score were the Panic $(\beta=.23)$ and Avoidance $(\beta=.24)$ decision-making styles. The Lack of Information scale score was best predicted by the Panic decision-making style ( $\beta$ $=.23$ ), the External Conflicts scale score by the Panic and Impulsive decision-making style ( $\beta=.13$ in both cases), and the strongest predictor of Dysfunctional Beliefs scale score was the Panic decision-making style. With regard to decision-making styles, the Panic style turned out to be related to more difficulties in all domains of career decision-making and therefore seems to be the least productive. A somewhat greater possibility of difficulties in all domains of career decision making, with an exception of External conflicts, was found for girls. 


\section{Discussion}

The aim of our study was to examine how students' different decision-making styles and their gender predict the presence of possible difficulties in their process of career decision-making at the end of secondary school when they have to decide about their future education/study programme. The difficulties are divided into cognitive or emotional difficulties and could represent an important obstacle in making a career choice or, as several authors (e.g., Osipow, Carney, \& Barak, 1976; Saka \& Gati, 2007; Sidiropoulou-Dimakakou \& Drosos, 2010) emphasize, the reason for their career indecision.

First, we found significant gender differences in three domains of difficulties in career decision-making (on the Internal Conflicts, External Conflicts, and Dysfunctional beliefs scale scores). It turned out that girls experienced all difficulties in the mentioned areas more strongly. In addition, we found significant gender differences in two decision-making styles. The panic decision-making style was more pronounced in girls and the impulsive decision-making style was more pronounced in boys. Although the effect sizes expressed with Cohen's $d$ were small to medium (Table 1) and despite the fact that previous studies regarding the connections between decision-making styles and gender were not consistent, we decided to include gender as a predictor in the regression model.

Moderate correlations were found between External Conflicts and Internal Conflicts scores and Lack of Information score and a high correlation was found between Lack of Information score and Internal Conflicts score. However, it is interesting that Dysfunctional beliefs score was not associated with other categories of career decision-making difficulties or any of the decision-making styles. This could indicate that dysfunctional beliefs represent a relatively autonomous, independent psychological construct. It seems that numerous students have prejudice, unreasonable expectations and believe in various career myths. Such dysfunctional thoughts make the career decision-making procedure harder and often force students to avoid it totally or transfer the responsibility of choosing to significant others (Sidiropoulou-Dimakakou, Mylonas, Argyropoulou, \& Tampouri, 2012). Our results confirm the idea that dysfunctional beliefs impede the process of making a career decision (Austin, Wagner, \& Dahl, 2003; Sampson, Peterson, Lenz, Reardon, \& Saunders, 1998), which leads us to a conclusion that we have to pay special attention to them during the career counselling of students. Another possibility is that such results are related to the low internal consistency of the Dysfunctional Beliefs scale $(\alpha=.62)$, which was found and warned about by the authors in previous studies (e.g. Babarović \& Šverko, 2018; Gati \& Saka, 2001). 


\section{Predictors of Career Decision-Making}

In regression analyses, the predictors (gender and decision-making styles) explained the largest amount of variance in internal conflicts in career decisionmaking, which is in line with the results of other authors (e.g., Thompson \& Subich, 2006). In our study, exploratory factor analysis yielded the Internal Conflicts scale that included items regarding lack of or unclear information about oneself (one's abilities and personality characteristics), incompatibility of one's abilities and characteristics with demands of a study programme/occupation, and individual's general difficulties in deciding. Hence, this scale was the largest and had the most heterogeneous content. With the regression model, we were able to explain one-sixth of variance in difficulties regarding Lack of Information scale score. These results are similar to the findings of previous studies (e. g., Germeijs \& De Boeck, 2003). However, the variance in External conflicts and Dysfunctional beliefs scale scores was explained to a smaller degree.

\section{Gender as a Predictor of Career Decision-Making Difficulties}

Some researchers (e.g., Betz \& Fitzgerald, 1993; Eccles, 1994; Fitzgerald, Fassinger, \& Betz, 1995; Rojewski \& Hill, 1998) emphasize that gender powerfully and persistently affects the occupational behaviour during adolescence. In our study, gender was a significant predictor of all categories of career decision-making difficulties, except of External Conflicts scale score where it had no predictive power (Table 3). The fact that boys reported less internal conflicts, less dysfunctional beliefs and smaller lack of information could lead to an inappropriate conclusion that boys have less career decision-making difficulties. For that reason, it is sensible to associate these results with significantly more expressed impulsive decision-making style in boys. This indicates that they do not put as much effort and attention into making a decision about choosing a future study programme as girls do. Therefore, they might not be aware of which information they lack or would need and they reflect about themselves and study programme demands less, which results in fewer internal conflicts (Tuinstra et al., 2000).

It seems that boys and girls all need career counselling and an elaborated career plan, but the reasons for this may be different for each gender. Counselling should stimulate boys to explore their abilities, personal characteristics and study programme/occupation demands, which they would otherwise do less intensively. In girls, however, counselling might decrease the effect of panic decision-making style by helping them to make an early career plan so that they have enough time to collect various information about themselves, study programmes/occupations and to coordinate this information. 


\section{Predictors of Individual Career Decision-Making Difficulties}

The adaptive - self-confident decision-making style turned out to be a significant protective factor for career decision-making difficulties in the domains of internal conflicts, lack of information and external conflicts (Table 3). Students with self-confident style (or rational style by Baron, 2000) thoughtfully approach the process of making a career choice. They gather information about themselves and study programmes/occupations, weigh up advantages and disadvantages and synthesize all information to achieve optimal career decisions (Gati et al., 2012). They consider and reflect on different options and, most importantly, focus relatively quickly on one particular solution - they choose one or two study programmes (Sampson, Reardon, Peterson, \& Lenz, 2004). Bimrose and Barnes (2007) named such individuals in a working environment as evaluative and strategic careerists. We find these terms useful also for describing students in the process of making a career decision.

The Panic Decision-Making Style score was the strongest predictor of Internal Conflicts and Lack of Information scores and somewhat weaker for External Conflicts and Dysfunctional Beliefs scores. These results were expected since panic or its related intuitive style (Gati et al., 2012) are characterized by basing decisions mainly on intuitions and feelings. Such style is accompanied by (prevailing) feelings of tension, agitation and panic, generated by student's solely thinking about having to decide about future study programme, especially when the circumstances demand quick decisions. On a behavioural level, this means that student avoids tension by thinking neither about how to collect the information about study programmes/occupations he/she needs nor about what he/she should do with the information, which obviously results in lack of information. Such circumstances in students with (predominantly) panic decision-making style predict also more extensive external conflicts with their significant others (e.g., parents), who encourage or (even) force them to make a career choice.

The Avoidant Decision-Making Style score was also an important (positive) predictor of career decision-making difficulties in the domains of internal conflicts and lack of information. Students with predominantly avoidant style procrastinate with making a decision, do not like taking responsibilities for making a decision or hand the decision over to somebody else. The base of this style is extreme lack of self-confidence, which in our study has been indicated also through the highest negative correlation of this score with Self-Confident Decision-Making Style score, or the need for conformity. Such a student typically does not want to be different from his/her peers or wishes to please others (e.g., parents).

The Impulsive Decision-Making Style score also turned out to be a significant, but relatively weak predictor of External Conflicts score (Table 3). This connection was expected, as it can easily be imagined that students who do not pay special attention to making a decision or want to complete the decision-making process as 
quickly as possible (Gati et al., 2012) have conflicts with their significant others, most often their parents. Parents typically care about their children and are aware of the importance of a suitable career choice. They force or pressure them to make a decision. However, it is often the case that neither parents nor children know how to deliberately approach this process.

\section{Study Limitations and Practical Career Counselling Implications}

First, it is important to point out that the internal-consistency reliability of the Dysfunctional Beliefs scale was low (.62). The problem with this scale was highlighted also by other studies, made in different cultural contexts - in the European countries (Babarović \& Šverko, 2018; Zagoričnik \& Pečjak, 2007), Israel (Gati \& Saka, 2001), Far East (Tien, 2005) and in the USA (Kelly \& Lee, 2002). In future studies, the reliability of this scale should be improved, especially given the fact that this scale in the Slovenian version has only 3 items. The second limitation of the study is that data were collected on an age-homogenous pattern of adolescents (17-18 years old) who were finishing secondary school. Therefore, it is not possible to generalize these results to all adolescents. In future studies, it would be necessary to investigate possible differences in the influence of decision-making styles on career decision-making in different periods of adolescence (e.g., at the end of elementary school).

A counsellor being familiar with students' decision-making styles can pursue a career guidance, taking into consideration their less adaptive decision-making styles by empowering them in the weaker aspects of their decision-making, thereby preventing larger difficulties in making a career choice. For example, by students with pronounced avoidance or impulsive decision-making style, it is reasonable to start a planned career counselling earlier, e.g., at the end of the second or at the beginning of the third year of a four-year secondary school. Further, counsellors should lead students through this process with a lot of structure, i.e. make a specific career plan with clear time dynamics. In addition, counsellors have to encourage students to carry out the assignments they agreed upon and monitor how they have achieved the short-term goals. By students with prevailing panic decision-making style, a counsellor might help by constructing a structured career plan with smaller steps, which enable students to collect and coordinate information about themselves with the information about the future study programme/occupation step-by-step. 


\section{References}

Albion, M. J. (2000). Career decision-making difficulties of adolescent boys and girls. Australian Journal of Career Development, 9(2), 14-19.

Austin, R. K., Wagner, B., \& Dahl, D. (2003). Reducing negative career thoughts in adults. International Journal of Disability Community and Rehabilitation, 2(2), 25-37.

Babarović, T., \& Šverko, I. (2011). Profesionalna zrelost učenika viših razreda osnovnih škola [Vocational maturity of primary school students in Croatia]. Suvremena psihologija, 14(1), 91-108.

Baron, J. (2000). Thinking and deciding. Cambridge: Cambridge University Press.

Betz, N. E., \& Fitzgerald, L. F. (1993). Individuality and diversity: Theory and research in counselling psychology. Annual Review of Psychology, 44(1), 343-381.

Bimrose, J., \& Barnes, S. A. (2007). Styles of career decision-making. Australian Journal of Career Development, 16(2), 20-28. doi:10.1177/103841620701600205

Brown, J. E., \& Mann, L. (1990). The relationship between family structure and process variables and adolescent decision-making. Journal of Adolescence, 13(1), 25-37. doi:10.1016/0140-1971(90)90039-A

Cenkseven-Önder, F. (2012). The influence of decision-making styles on early adolescents' life satisfaction. Social Behavior and Personality: An International Journal, 40(9), 1523-1536. doi:10.2224/sbp.2012.40.9.1523

Čerče, M., \& Pečjak, S. (2007). Vloga osebnostnih in motivacijskih dejavnikov pri poklicnem odločanju [The role of personality and motivational factors in occupational decisionmaking]. Psihološka obzorja, 16(4), 27-42.

Eccles, J. S. (1994). Understanding women's educational and occupational choices: Applying the Eccles et al. model of achievement-related choices. Psychology of Women Quarterly, 18(4), 585-609. doi:10.1111/j.1471-6402.1994.tb01049.x

Eurydice (n. d.). National education systems, Slovenia, Chapter 6: Upper secondary and postsecondary non-tertiary education. Retrieved from https://eacea.ec.europa.eu/ nationalpolicies/eurydice/content/upper-secondary-and-post-secondary-non-tertiary-education34_en

Farrar, L. C. (2009). Relationships between vocational decision-making styles and career decision-making difficulties of low socio-economic status high school students in residential education. Doctoral dissertation, Marywood University.

Fitzgerald, L. F., Fassinger, R. E., \& Betz, N. E. (1995). Theoretical advances in the study of women's career development. In W. B. Walsh \& S. H. Osipow (Eds.), Handbook of vocational psychology (2nd ed., pp. 331-365). Mahwah, NJ: Erlbaum.

Franken, I. H. A., \& Muris, P. (2005). Individual differences in decision making. Personality and Individual Differences, 39(5), 991-998. doi:10.1016/j.paid.2005.04.004 
Friedman, I. A., \& Mann, L. (1993). Coping patterns in adolescent decision-making: An Israeli-Australian comparison. Journal of Adolescence, 16(2), 187-199. doi:10.1006/ jado.1993.1016

Galotti, K. M., Ciner, E., Altenbaumer, H. E., Geerts, H. J., Rupp, A., \& Woulfe, J. (2006). Decision-making styles in a real-life decision: Choosing a college major. Personality and Individual Differences, 41(4), 629-639. doi:10.1016/j.paid.2006.03.003

Gati, I., Gadassi, R., \& Mashiah-Cohen, R. (2012). Career decision-making profiles vs. styles: Convergent and incremental validity. Journal of Vocational Behavior, 81(1), 2-16. doi:10.1016/j.jvb.2012.03.004

Gati, I., Krausz, M., \& Osipow, S. H. (1996). A taxonomy of difficulties in career decision making. Journal of Counseling Psychology, 43(4), 510-526. doi:10.1037/0022-0167. 43.4.510

Gati, I., Krausz, M., \& Osipow, S. H. (2011). Abridged professional manual for the Career Decision-making Difficulties Questionnaire (CDDQ). Retrieved from http://kivunim. huji.ac.il/cddq/CDDQ-Manual-3-2011.doc

Gati, I., Landman, S., Davidovitch, S., Asulin-Peretz, L., \& Gadassi, R. (2010). From career decision-making styles to career decision-making profiles: A multidimensional approach. Journal of Vocational Behavior, 76(2), 277-291. doi:10.1016/j.jvb.2009. 11.001

Gati, I., \& Saka, N. (2001). High school students' career related decision-making difficulties. Journal of Counselling and Development, 79(3), 331-340. doi:10.1002/j.1556-6676. 2001.tb01978

Germeijs, V., \& De Boeck, P. (2003). Career indecision: Three factors from decision theory. Journal of Vocational Behavior, 62(1), 11-25. doi:10.1016/S0001-8791(02)00055-6

Harren, V. A. (1979). A model of career decision making for college students. Journal of Vocational Behavior, 14(2), 119-133. doi:10.1016/0001-8791(79)90065-4

Janis, I. L., \& Mann, L. (1977). Decision making: A psychological analysis of conflict, choice, and commitment. New York, NY, US: Free Press.

Jorgensen, T. D., Pornprasertmanit, S., Schoemann, A. M., \& Rosseel, Y. (2018). semTools: Useful tools for structural equation modeling. $R$ package version 0.5-0. Retrieved from https://CRAN.R-project.org/package=semTools

Kelly, K. R., \& Lee, W. C. (2002). Mapping the domain of career decision problems. Journal of Vocational Behavior, 61(2), 302-326. doi:10.1006/jvbe.2001.1858

Osipow, S. H., Carney, C. G., \& Barak, A. (1976). A scale of educational-vocational undecidedness: A typological approach. Journal of Vocational Behavior, 9(2), 233-243. doi:10.1016/0001-8791(76)90081-6

Pečjak, S., \& Košir, K. (2007). Personality, motivational factors and difficulties in career decision-making in secondary school students. Psihologijske teme, 16(1), 141-158. 
Pečjak, S., Pirc, T., Podlesek, A., Tuinstra, J., van Sonderen, F. L. P., Groothoff, J. W., ... van den Post, D. (2018). Vprašalnik stilov odločanja: priročnik [Adolescent decision making styles questionnaire: manual]. Ljubljana: Zavod Republike Slovenije za zaposlovanje.

Pečjak, S., Podlesek, A., Pirc, T., Gati, I., Krausz, M., \& Osipow, S. (2018). Vprašalnik težav pri kariernem odločanju: Priročnik [The career decision-making difficulties questionnaire: manual]. Ljubljana: Zavod Republike Slovenije za zaposlovanje.

Phillips, S. D., Pazienza, N. J., \& Walsh, D. J. (1984). Decision making styles and progress in occupational decision making. Journal of Vocational Behavior, 25(1), 96-105. doi:10.1016/0001-8791(84)90039-3

Rojewski, J. W., \& Hill, R. B. (1998). Influence of gender and academic risk behavior on career decision making and occupational choice in early adolescence. Journal of Education for Students Placed at Risk, 3(3), 265-287. doi:10.1207/ s15327671espr0303_4

Rosseel, I. (2012). lavaan: An R package for Structural equation modeling. Journal of Statistical Software, 48(2), 1-36. Retrieved from http://www.jstatsoft.org/v48/i02/

Sager, K. L., \& Gastil, J. (1999). Reaching consensus on consensus: A study of the relationships between individual decision-making styles and use of the consensus decision rule. Communication Quarterly, 47(1), 67-79. doi:10.1080/ 01463379909370124

Saka, N., \& Gati, I. (2007). Emotional and personality-related aspects of persistent career decision-making difficulties. Journal of Vocational Behavior, 71(3), 340-358. doi:10.1016/j.jvb.2007.08.003

Sampson Jr, J. P., Peterson, G. W., Lenz, J. G., Reardon, R. C., \& Saunders, D. E. (1998). The design and use of a measure of dysfunctional career thoughts among adults, college students, and high school students: The Career Thoughts Inventory. Journal of Career Assessment, 6(2), 115-134. doi:10.1177/106907279800600201

Sampson, J. P., Reardon, R. C., Peterson, G. W., \& Lenz, J. G. (2004). Career counseling and services: A cognitive information processing approach. Belmont, CA: Thomson/ Brooks/Cole.

Savickas, M. L., \& Porfeli, E. J. (2011). Revision of the career maturity inventory: The adaptability form. Journal of Career Assessment, 19(4), 355-374.

Scott, S. G., \& Bruce, R. A. (1995). Decision-making style: The development and assessment of a new measure. Educational and Psychological Measurement, 55(5), 818-831. doi:10.1177/0013164495055005017

Sidiropoulou-Dimakakou, D., \& Drosos, N. (2010). Career aspirations, career maturity and dysfunctional career views of adolescents belonging to different cultural groups. Review of Counselling and Guidance, 92(93), 123-136.

Sidiropoulou-Dimakakou, D., Mylonas, K., Argyropoulou, K., \& Tampouri, S. (2012). Career decision-making difficulties, dysfunctional thinking and generalized selfefficacy of university students in Greece. World Journal of Education, 2(1), 117-130. doi:10.5430/wje.v2n1p117 
Super, D. E. (1990). A life-span, life-space approach to career development. In D. Brown, \& L. Brooks (Eds.), Career choice and development: Applying contemporary theories to practise (pp. 197-261). San Francisco: Jossey-Bass.

Super, D. E., Savickas, M. L., \& Super, C. M. (1996). The life-span, life-space approach to careers. In D. Brown \& L. Brooks (Eds.), Career choice and development (pp. 121178). San Francisco: Jossey-Bass.

Taštanoska, T. (2014). Vzgoja in izobraževanje v Republiki Sloveniji. Ljubljana: Ministrstvo za izobraževanje, znanost in šport.

Thompson, M. N., \& Subich, L. M. (2006). The relation of social status to the career decisionmaking process. Journal of Vocational Behavior, 69(2), 289-301. doi:10.1016/j.jvb. 2006.04.008

Tien, H. L. S. (2005). The validation of the career decision-making difficulties scale in a Chinese culture. Journal of Career Assessment, 13(1), 114-127. doi:10.1177/ 1069072704270327

Tuinstra, J., Van Sonderen, F. L. P., Groothoff, J. W., Van den Heuvel, W. J. A., \& Post, D. (2000). Reliability, validity and structure of the Adolescent Decision Making Questionnaire among adolescents in the Netherlands. Personality and Individual Differences, 28(2), 273-285. doi:10.1016/S0191-8869(99)00096-3

Watts, A. G. (1993). Promoting careers: Guidance for learning and work. London: Heinemann.

Zagoričnik, M., \& Pečjak, S. (2007). Težave slovenskih srednješolcev pri odločanju o nadaljnjem izobraževanju. Psihološka obzorja, 16(4), 7-26.

Zhou, D., \& Santos, A. (2007). Career decision-making difficulties of British and Chinese international university students. British Journal of Guidance and Counselling, 35(2), 219-235. doi:10.1080/03069880701256684

\title{
Stilovi odlučivanja kao prediktori poteškoća pri donošenju profesionalnih odluka kod mladića i djevojaka završnih razreda srednje škole
}

\begin{abstract}
Sažetak
Cilj je ovoga istraživanja bio ispitati predviđaju li različiti stilovi odlučivanja poteškoće u donošenju profesionalnih odluka, odnosno, poteškoće u odabiru smjera nastavka obrazovanja kod srednjoškolaca. Preciznije, ispitano je kako su samopouzdani stil i tri maladaptivna stila odlučivanja, izbjegavajući, panični i impulzivni, povezani s poteškoćama u donošenju odluka vezanih uz profesionalnu orjentaciju: internalnim i eksternalnim konfliktima, nedostatku informacija i disfunkcionalnim vjerovanjima. Uzorak se sastojao od 792 učenika završnih razreda 26 srednjih škola u Sloveniji. Korišteni su Upitnik poteškoća u donošenju profesionalnih odluka (engl. Career Decision Difficulties Questionnaire; CDDQ) i Upitnik stilova odlučivanja adolescenata (engl. Adolescent Decision Making Questionnaire; ADMQ), koji su adaptirani na slovenski jezik.
\end{abstract}


Rezultati su pokazali da se mladići češće nego djevojke koriste samopouzdanim i impulzivnim, a rjeđe paničnim stilom odlučivanja. Nadalje, mladići izvještavaju o nižim internalnim konfliktima, manjem nedostatku informacija i nižim disfunkcionalnim vjerovanjima. Između skala CDDQ-a pronađena je visoka povezanost skala internalnih konflikata i nedostatka informacija, a umjerena je povezanost ovih dviju skala sa skalom eksternalnih konflikata. Korelacije među skalama ADMQ-a u rasponu su od niskih do umjerenih: rezultat na skali samopouzdanog stila odlučivanja negativno je povezan s rezultatima na skalama svih triju maladaptivna stila. Panični stil odlučivanja najbolji je prediktor rezultata na skali nedostatka informacija, dok su panični i impulzivni stil odlučivanja prediktori rezultata na skali eksternalnih konflikata. Također, panični je stil odlučivanja najbolji prediktor rezultata na skali disfunkcionalnih vjerovanja. Izraženiji panični stil povezan je s većim poteškoćama u svim domenama donošenja profesionalnih odluka, osobito kod djevojaka. Raspravljene su praktične implikacije dobivenih rezultata u vidu savjetovanja o donošenju odluka u vezi s profesionalnom orijentacijom.

Ključne riječi: poteškoće u donošenju profesionalnih odluka, stilovi odlučivanja, srednjoškolci, spol

Primljeno: 12.3.2019. 